\title{
Dutch Greylag Geese Anser anser: migrants or residents?
}

\author{
Grågåsen Anser anser $i$ Holland: fytt- eller stannfågel?
}

BEREND VOSLAMBER, ELISE KNECHT \& DAVID KLEIJN

\begin{abstract}
During the last twenty years more than 2500 Greylag Geese have been neck-banded at different moulting places in the Netherlands. Almost all birds have been re-sighted at least once. We used the 45,000 re-sightings that had been reported during the winter months October through February 1994-2010 in order to determine the migratory movements. We assume that the moulting site is about the same as the breeding site. Geese banded in west, central and south Netherlands wintered on average within $10 \mathrm{~km}$ from the breeding site. Geese from the northern part showed a much larger average distance, this was mainly due to a large proportion of them wintering

in Spain. However, this habit changed during the course of the study, and in recent years only a small proportion wintered in Spain. We estimate that currently over ninety percent of the Dutch Greylag Geese are resident and winter close to their breeding site.

Berend Voslamber, SOVON Dutch Centre for Field Ornithology, P.O. Box 6521, NL-6503 GA Nijmegen, The Netherlands. E-mail: berend.voslamber@sovon.nl Elise Knecht and David Kleijn, Alterra, Centre for Ecosystem Studies, P.O. Box 47, NL-6700 AA, Wageningen, The Netherlands
\end{abstract}

\section{Introduction}

In the first half of the 20th century the Greylag Goose was a migratory species which bred in Scandinavia and wintered in Spain. Since the 1970s the Greylag Goose population is rapidly expanding in size and range due to reduced hunting pressure and improved foraging conditions on heavily fertilized agricultural grasslands (van Eerden et al. 1996, Madsen et al. 1999). In recent decades, climate change resulted in significant increases in winter temperatures (Kleijn et al. in press). At the same time there are indications that the Greylag Goose population is changing its migratory behavior. For example, almost 50,000 Greylag Geese now winter in southern Sweden, a region where wintering was rare until the early 1990s (Nilsson 2009).

In the Netherlands the Greylag goose is a native species that went extinct in the beginning of the twentieth century. After a number of unsuccessful attempts to reintroduce the species it bred for the first time in 1961 (van den Bergh 1991). Between 1961 and 2009 the Dutch population grew with an average of $20 \%$ per year and now con- sists of approximately 190,000 individuals. From 1990 onward the number of ringed and especially neck-banded Greylag Geese has increased in the Netherlands (Buijs \& Thomson 2001). Despite the increased ringing and neck-banding efforts, little information is available about the migration patterns of Greylag Geese breeding in the Netherlands (Speek \& Speek 1984, Loonen \& de Vries 1995). On the contrary a lot of information has been published about birds from populations that use the Netherlands for staging in spring and autumn but not for breeding (Nordic Greylag Goose Working Group 1988, Nilsson 1990, Voslamber et al. 1993, Voslamber 1993, Andersson et al. 2001).

In this paper we briefly describe the Greylag Goose neck-banding programme in the Netherlands. We subsequently use the resightings from this neck-banding scheme between 1990 and 2010 to examine the migratory behaviour of the Dutch Greylag Goose population. We ask whether the migratory behaviour of Greylag Geese has changed over time and whether there are differences between geese from different regions or different sexes. 
Table 1. Number of birds colour-ringed per region 1990-2009, total number of observations per region (N) and average number of observations per individual bird (Mean). See Figure 1 for distribution of ringing sites over the Netherlands.

Antal färgmärkta fäglar per region 1990-2009, totalt antal observationer per region $(N)$ och medeltal observationer per individuell gås (Mean). Se Figur 1 för märkplatsernas läge i Nederländerna.

\begin{tabular}{lrrrrrrr}
\hline & \multicolumn{5}{c}{ Numbers colour-ringed Antal färgmärkta } & N & Mean \\
\cline { 2 - 6 } & $1990-1994$ & $1995-1999$ & $2000-2004$ & $2005-2009$ & Total & & \\
\hline North & 89 & 25 & 0 & 281 & 395 & 5221 & 13,2 \\
Mid & 0 & 109 & 230 & 508 & 847 & 80858 & 95,5 \\
West & 126 & 88 & 0 & 648 & 862 & 10219 & 11,9 \\
South & 0 & 0 & 143 & 266 & 409 & 5121 & 12,5 \\
\hline Total & 215 & 222 & 373 & 1703 & 2513 & 101419 & \\
\hline
\end{tabular}

\section{Material and methods}

\section{Catching and marking}

Between 1990 and 2010 over 2500 Greylag Geese have been individually marked with neckbands (Table 1, Figure 1). Greylag Geese were generally caught during their moulting period which, in the Netherlands, is mainly in June (end of May through half July). In most of the areas only adults with young were caught, but in 2008 and 2009 a number of large groups of non-breeding Greylag Geese were caught in some of the areas. The birds were driven to walk or swim in the direction of a funnelshaped net ending in a corral (e.g. Persson 1994).

The $4.8 \mathrm{~cm}$ diameter and $4.5 \mathrm{~cm}$ high neck collars used for Greylag Geese in the Netherlands are dark green with white unique inscriptions. Under good light conditions, codes can be read from a distance of up to 500-600 meters. In addition to neck collars, all birds received a metal ring from the Dutch Centre for Avian Migration and Demography on one of their tarsus. From 1999 onwards most birds were also ringed with a coloured leg ring with the same code as the neckband. By ringing the birds in three ways (neckband, colour leg ring, metal ring) we were able to see if there is loss of bands.

\section{Resightings}

Until January 2010 over 100,000 observations of neck-banded Greylag Geese have been reported.

Information about the Greylag Geese neckbanding project has been published in several local papers. Observers who reported sightings received a list with the other sightings of 'their' birds. Observations initially came via regular mail or email. Recently, observations can be reported through the website www.geese.org (in Dutch, English and German). After the creation of this website a lot of observations, also from the past were entered by the observers through google-maps. The website is considered to be motivating to volunteers because they can check online where the bird they have observed has been ringed and which other observations of the same bird have been made.

Mis-identification of neck collars does occur due

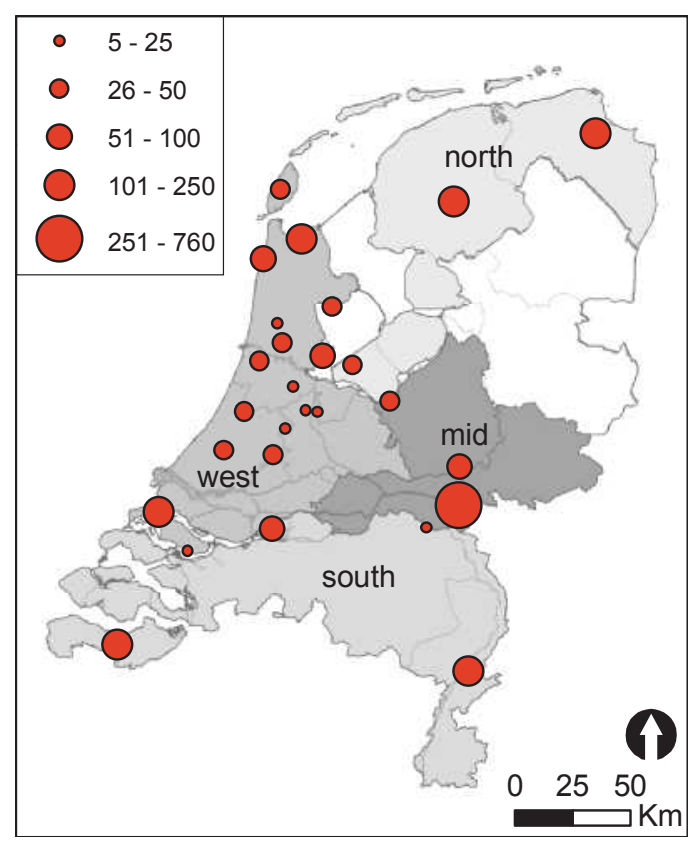

Figure 1. Distribution of ringing sites in different regions of the Netherlands 1990-2010. Point size indicates number of ringed birds.

Märkplatsernas läge inom olika regioner $i$ Nederländerna 1990-2010. Punktens storlek anger antal märkta fåglar. 
to distance to the birds or to weather conditions. Mis-readings in the areas with a lot of sightings do not affect the results, but mis-readings outside the main areas do have an effect on results. We deleted all obvious mis-readings and incomplete readings from the data-base. Besides that we tried to check all observations on possible mis-identification and if possible changed them.

\section{Analyses}

To analyse the migration patterns and to examine whether they had changed between 1994 and 2010, we selected all observations done during the winter months (October, November, December, January, February) between 1 January 1994 and 1 January 2010. Very few resightings were available from 1990-1993, therefore they were omitted from the analyses. This selection resulted in about 45.000 records for each of which we calculated the Euclidian distance between the ringing site and the observation site. To check whether birds from different parts of the Netherlands displayed different migration patterns we subdivided the Netherlands in four regions (Figure 1).

As geese were generally caught during moulting and geese may moult in areas at considerable distance from their breeding area, we also selected resightings of geese which were known to be older than 4 years and that had been observed in an area during the breeding period (1 March-15 April). We assumed that the areas in which these birds were observed during that period of the year were their actual breeding areas. The results of the analyses in this smaller subset of resightings were similar to the one using the ringing site. In the remainder of the paper we will therefore only present results relating ringing site to resightings in the winter period.

The resighting rate was much higher in the Ooijpolder area, due to higher resighting numbers by the first author, than in any other area in the Netherlands. This could have biased the estimated dispersal distance because in this area observer effort near the ringing site was much larger than far from the ringing site. To account for this, we used a random selection of 10.000 observations from the Ooijpolder area in the statistical analyses.

As resightings of individual geese are not independent we used Generalized Linear Mixed Models with a normal distribution and a logarithmic link function to analyze the data. Distance between ringing site and resighting was the dependent variable and "year of observation", "month of observa- tion", "ringing region" and "sex" were explanatory fixed variables. Goose identity entered the model as a random variable. Wald tests were used to examine the significance of variables. The same was done with selected data after 2000 instead of after 1994, because the number of observations over the years 2000-2010 was more constant. Since 2000 there is also a more constant average distance between ringing and wintering site. We wanted to see if the influence of the factors region, month, year and sex was the same for this period than for the whole period.

Most birds winter close to their breeding site, so we wanted to know whether there are differences between years/sex/region. From the birds with a long distance dispersal pattern, we were interested in what they have in common. The graphs and tables produced to analyse this part of the study were done using Pivot table and extracting the data needed.

All analyses were carried out using the statistical software Genstat (Payne et al. 2002).

\section{Results}

\section{Resightings}

Almost all marked birds ( $>99 \%)$ were seen at least once after ringing. The frequency of resighting differed strongly between the different study areas (Table 1). In one of the areas (Ooijpolder, Nijmegen) there is an ongoing detailed study to investigate the breeding performances of Greylag Geese. In this area the first author was out in the field at least once a week and most of the birds in this area were observed regularly. In the period 1997 to 2009 over 80.000 observations were collected of the 600 birds that had been ringed in this area (average number of observations per individual: 130, range 0 to 1656).

In the other study areas the frequency of observation was much lower and depended on the number of observers and their enthusiasm to go out in the field as often as possible. Of the approximately 1700 birds ringed in these areas about $20.500 \mathrm{ob}-$ servations have been collected (average 12 per individual, range from 0 to 230). Nevertheless, also in these areas hundreds of observations were collected which allowed us to determine (differences in) dispersal patterns reliably (see below).

\section{Factors explaining migration patterns}

Winter dispersal distances did not differ between sexes. On average males flew further $(34.1 \mathrm{~km})$ 


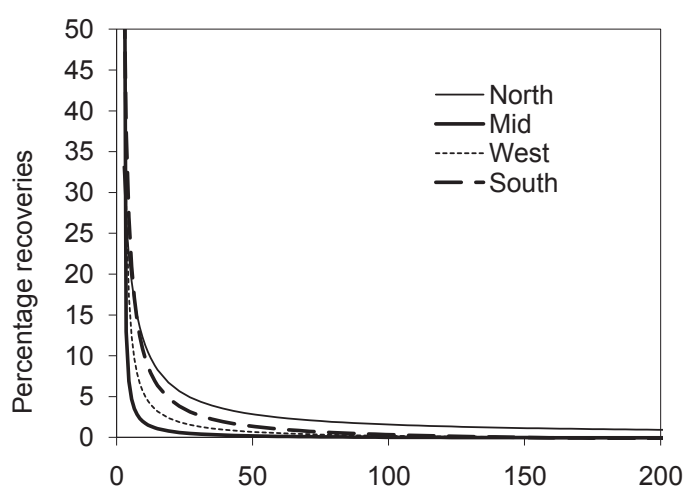

Figure 2. Modelled relation between distances and observations (\%) for Dutch Greylag Geese from four regions in winter.

Modell för relationen mellan anvstånd och andel observationer (\%) för nederländska grågäss från fyra regioner vintertid. than females $(22.8 \mathrm{~km})$ but the difference was not significant (Wald statistic $=2.22$, d.f. $=2, \mathrm{p}>0.05$ ).

Birds ringed in different regions in the Netherlands did show significant differences in migration distance (Wald statistic $=297.34$, d.f. $=3, \mathrm{p}<0.001$ ). Birds from areas in the north travelled a much larger distance $(281.9 \mathrm{~km})$ than those from the West $(8.9 \mathrm{~km})$, the Centre $(2.5 \mathrm{~km})$ or the South $(7.9 \mathrm{~km})$. The high average dispersal distance of geese from the northern region is largely caused by $17 \%$ of the neck-banded individuals that winter in Spain. All in all $75 \%$ of the birds that have been seen in Spain, Italy or France originate from the region North.

Despite the significant regional differences, in all four regions the percentage of birds migrating a certain distance decreased very rapidly with increasing distance to the ringing sites (Figure 2). Even in the northern region only a small proportion of birds

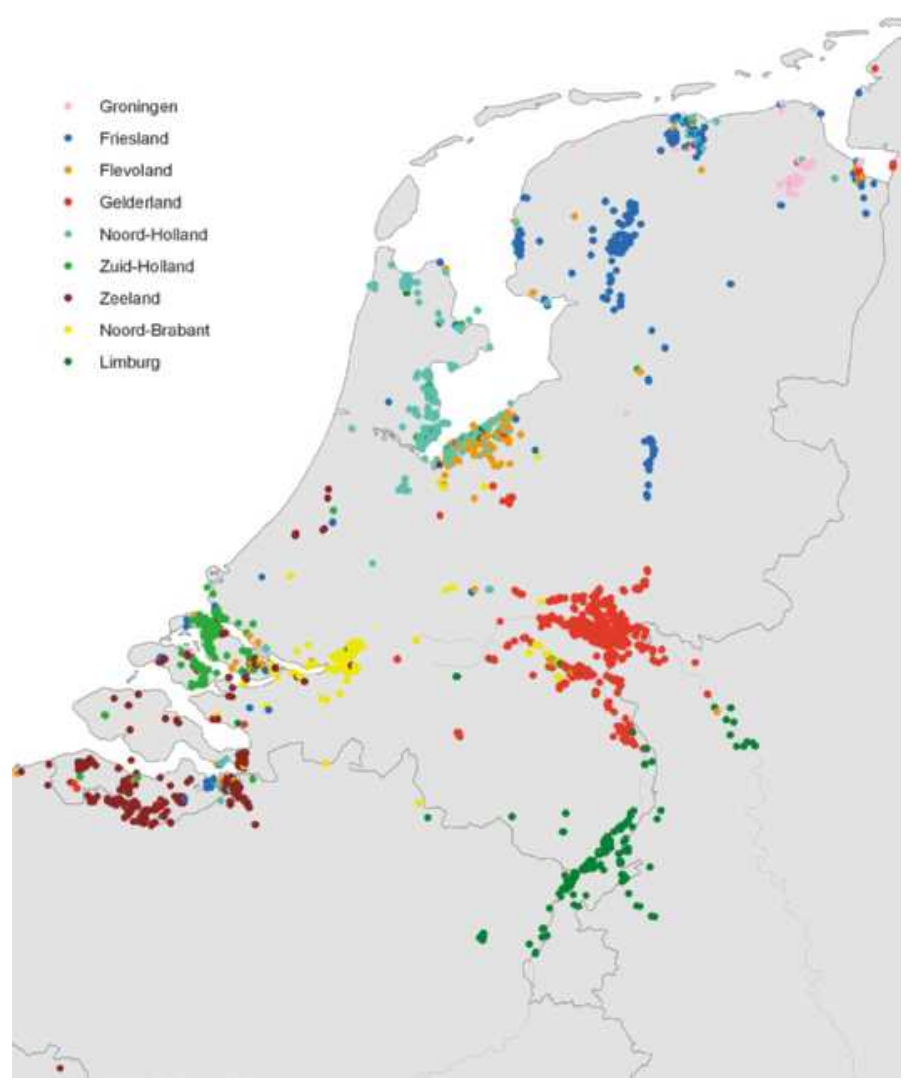

Figure 3. Observations within the country of neck/banded Greylag Geese from different ringing sites in the Netherlands.

Observationer inom landet av halsmärkta grågäss från olika märkplatser i Nederländerna. 
Figure 4. Observations outside the borders of the country of neck/banded Greylag Geese from different ringing sites in the Netherlands.

Observationer utanför landet av halsmärkta grågäss från olika regioner $i \mathrm{Ne}$ derländerna.

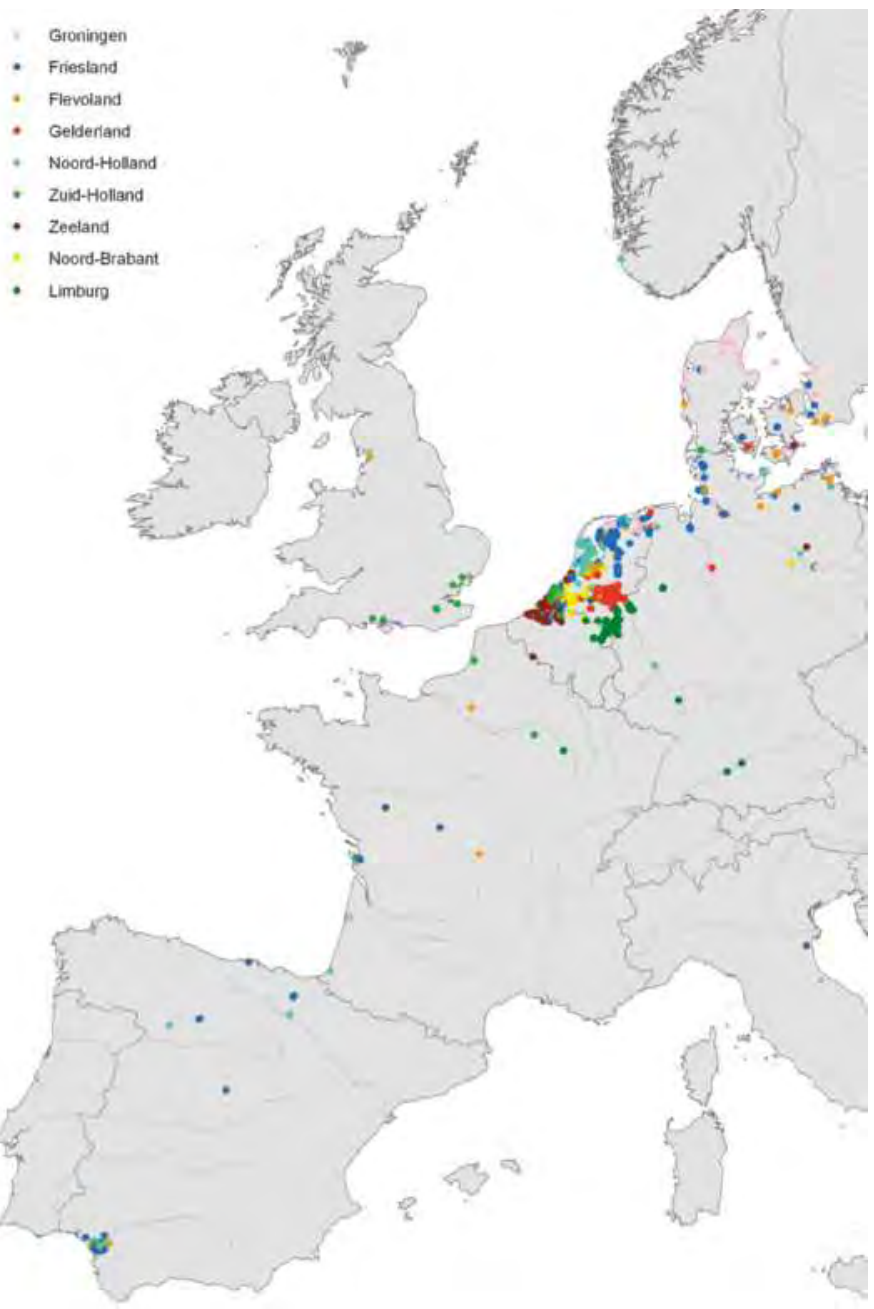

disperse over large distances. Most of the observations of neck-banded geese in the Netherlands $(\mathrm{n}=$ 43,692 ) were done in or close to the different ringing-areas. As a result, all Dutch populations seem to have their own 'home range' (Figure 3). Of course there is some overlap in 'home range area', but this overlap is relatively small. For the birds dispersing outside the Netherlands ( $\mathrm{n}=1376$ observations of 89 birds), dispersal distances are very variable. Most of the birds observed outside the Netherlands were from ringing sites close to the border and were spotted in the neighbouring countries Germany and Belgium just on the other side of the border. A small number of birds were reported further away (Figure 4 ) and only $0.78 \%$ of all neck-banded birds had been resighted at distances of over $1000 \mathrm{~km}$ from the ringing location. These birds were resighted in Spain, France and Italy and existed of an equal proportion of females $(52 \%)$ and males (45, sex of 3\% of the birds was unknown).

Migration patterns were linked to ringing sites. For example, all but one of the birds migrating to southern Europe came from just three locations that were at least $80 \mathrm{~km}$ apart: De Deelen and Oostvaardersplassen in region North and Waterland in region West. In contrast, many birds from the ringing site 'Tetjehorn' in Groningen (which is just 70 km from De Deelen) migrated northward and wintered partly in northern Denmark and southern Sweden.

The average migration distance of neck banded Greylag Geese changed drastically over the course of the last two decades (Figure 5). From 1994 to 


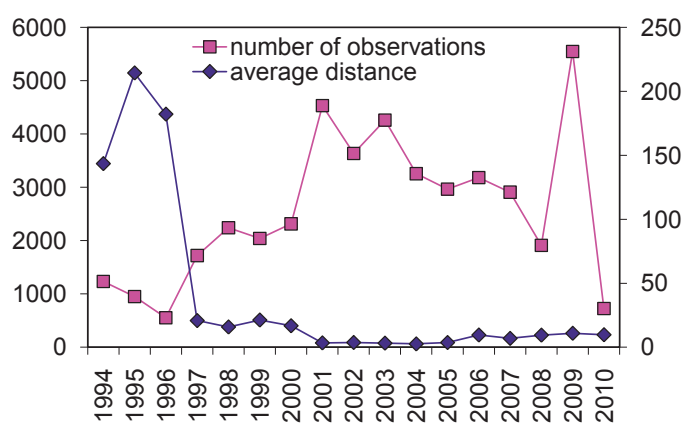

Figure 5. Change in average migration distance of Dutch Greylag Geese in time, 1994-2010. Y-axes: left observations, right kilometers.

Förändring av genomsnittliga flyttdistansen för nederländska grågäss perioden 1994-2010.

1996 a large proportion of birds were wintering in Spain resulting in average dispersal distances of $200-250 \mathrm{~km}$. Nowadays, the data that we have show that most of the birds stay in the surroundings of their breeding area and distances of over 200 $\mathrm{km}$ are extremely rare. It must be noted however, that observations from the Oostvaardersplassen, De Deelen and Waterland sites make up a large proportion of the total number of observations before 1996. In Oostvaardersplassen and Waterland no birds were neck-banded after 1998, however, in De Deelen area neck banding was resumed after 2005. Three per cent of the birds that were neck-banded in that area after that year have been observed in Spain.

\section{Discussion}

Until recently the Greylag Goose has been seen as a migrating species (Cramp \& Simmons 1977), but during the last decades increasing numbers stay all year round on the breeding grounds (KampePersson 2002). Data about the migration of Dutch birds are lacking in the period between the onset of breeding around 1960 and the start of our study in 1990. In Scandinavia however the species dramatically changed its migrating behaviour during the last decades resulting in over 50,000 instead of almost no wintering birds (Nilsson 2009).

We think that nowadays over $90 \%$ of the Dutch Greylag Geese are residents. If this also has been the case in the early years after settlement is not clear, but during the first years of our study the number of birds seen in Spain has been much higher than during the last years. The reason for a resident population is not certain, but weather con- ditions seem a good explanation. Especially during the main period of our study winters were extremely mild according to the IJnsen-index (IJnsen 1991). Recent Dutch winters are much milder than they were in the past (www.knmi.nl). Interesting would be to analyse the influence of severe winter weather such as the one from 2009/2010 with a lot of snow in great parts of Northwest Europe. Where would Greylags go when they obviously cannot find food anymore? Would they go south? Or do they stay in the surrounding of their normal wintering area?

Another explanation could be that the hunting pressure is lower in the Netherlands than in Spain or France, which leads to higher winter survival of adult birds (Nilsson \& Persson 1996). Since some years so called foraging areas have been established where hunting is banned. Although hunting pressure outside these areas is still high $(80.000$ Greylag Geese shot in recent years; Kleijn et al. 2009) birds are save within the foraging areas.

A further explanation for a large proportion of resident birds, often mentioned by people in the field, could be that part of the population has mixed with feral geese, but in which amount this is the case is unclear and thus highly speculative. Future analyses of DNA could maybe give some clarity in this.

Our study shows that both within and between breeding populations there can be large differences in migration patterns. While in the study period most Greylag Geese wintered in the immediate surroundings of the ringing site, some individuals however still fly to southern Europe and others to Scandinavia for wintering. Where do these patterns come from? In theory, in most winters there is no reason to leave the country. In mild and normal winters the food availability seems to be enough to feed all the birds. If there are parts of the country where the birds should leave the breeding areas, these are the northern provinces (Groningen, Friesland) where winter conditions are more severe. It remains strange that part of these birds move northwards to northern Denmark, southern Sweden and southern Norway. Breeding Greylag Geese from these Scandinavian areas are known to migrate southwards to Spain in the past (Andersson et al. 2001).

It is surprising that birds from ringing sites that were in relatively short distance from each other can show completely different migrating strategies. As mentioned birds from 'Tetjehorn' migrate north to Scandinavia while birds from 'De Deelen' migrate to Spain and the ringing sites are only 70 
kilometer apart from each other. Also in other parts of the country we see differences like this. Birds from 'Scheelhoek' and 'Reeuwijk' in the province of Zuid-Holland partly winter in Great Britain while birds from 'De Biesbosch' and 'Zoetermeer' never have been seen so far to the west, although the distance between these ringing sites is only about 50 kilometer. One of the possible reasons for these differences between populations might be a founder effect.

Our results seem to indicate that an increasing proportion of the Dutch Greylag Geese population is overwintering near their breeding locations. However, care should be taken with this conclusion because data of neck-banded geese from breeding populations that disperse over large distances were only available during the first years of the study. Our data show, however, that only populations that were already well-established in the early 1990s had Greylag Geese dispersing over very large distances. If we assume that the breeding populations that were part of this study were selected randomly with respect to their migratory behaviour, our data would indicate that the chance that a random breeding population had geese dispersing over large distances was much higher in the early 1990s than after 2000. This would indirectly support our conclusion that over time the proportion of Greylag Geese that is over wintering in far away places is declining.

In the case of birds flying to Spain there seems to be a recent problem. During the late nineties several birds were reported from Coto Doñana in the southwest of the country. Since 2000 almost no birds are reported from at least that part of Spain anymore. Do our birds not migrate to Spain anymore, are they not reported anymore or is it a ringing effect? The birds flying to Spain almost all came from ringing sites where there is no ringing in recent years. The only exception is De Deelen in the province of Friesland. Maybe not surprisingly: almost all recent sightings of Dutch Greylag Geese in Spain were birds from this ringing area. The idea is that there are still Dutch (and Scandinavian (pers. com. Leif Nilsson)) birds going south, maybe renewed ringing in the areas Oostvaardersplassen en Waterland could give some clarity in this.

\section{Acknowledgements}

A warm thank you to all volunteers that helped with catching and ringing and resighting the geese. They are too numerous to mention them all, but we do like to mention the die harts notably Hennie van den Brink, Loes van den Bremer, Kell Eradus,
Chris van Turnhout and Frank Willems. We also like to mention Maarten J.J.E. Loonen who initiated neckbanding of Greylag Geese in the Netherlands in 1990. The contribution of EK \& DK and partly BV was made within the framework of the project "Populatiebeheer overzomerende Grauwe ganzen" (BO-02-013-005).

\section{References}

Andersson, Å., Follestad, A., Nilsson, L. \& Persson H. 2001. Migration patterns of Nordic Greylag Geese Anser anser. Ornis Svecica 11: 19-58.

Buijs, R.J. \& Thomson, D.L. 2001. Van 1911 tot en met 2000: een overzicht van geringde en teruggemelde vogels in Nederland. Op het Vinkentouw 95: 2-88. (in Dutch).

Cramp, S. \& Simmons, K.E.L. 1977. Handbook of the birds of Europe, the Middle East and North Africa: the birds of the Western Palearctic. Vol. 1. Oxford University Press, Oxford.

Eerden, M.R. van, Zijlstra, M., Roomen, M. van \& Timmerman, A. 1996. The respons of Anatidae to changes in agricultural shifts in the carrying capacity for wintering waterfowl. In: M. Birkan, J. Van Vessem, P. Havet, J. Madsen, B. Trolliet \& M. Moser (eds.), Proceedings of the Anatidae 2000 Conference, Starsbourg, France, 5-9 September 1994. Gibier Faune Sauvage, Game Wildl. 13: 681-706.

IJnsen, F. 1991. Karaktergetallen van de winters vanaf 1707. Zenit 18: 65-73. (in Dutch).

Kampe-Persson, H. 2002. Greylag Goose Anser anser. BWP Update 4: 181-216.

Kleijn, D. Jansman, H.A.H., Oord, J.G. \& Ebbinge, B.S. 2009. Effectiviteit verjaagmethoden in foerageergebieden met speciale aandacht voor verjaging met ondersteunend afschot. Alterra rapport 1792. (in Dutch).

Kleijn, D., Schekkerman, H., Dimmers, W.J., van Kats, R.J.M., Melman, T.C.P. \& Teunissen, W.A. 2010. Adverse effects of agricultural intensification and climate change on breeding habitat quality of Black-tailed Godwits $L i$ mosa l. limosa in the Netherlands. Ibis 152: 475-486.

Loonen, M.J.J.E. \& de Vries, C. 1995. De Grauwe Gans (Anser anser) als standvogel in ZW-Nederland. Limosa 68: 11-14. (in Dutch with English summary).

Madsen, J., Cracknell, G. \& Fox, A.D. (eds.) 1999. Goose populations of the Western Palearctic. A review of status and distribution. Wetlands International Publ. No. 48, Wetlands International, Wageningen, The Netherlands. National Environmental Research Institute, Rönde, Denmark.

Nilsson, L. 1990. Flevoland - an important moulting and staging area for Nordic Greylag Geese. Vogels in Flevoland 1990 (1) 45-53.

Nilsson, L. 2009. International waterfowl and goose counts in Sweden. Annual report 2008/09. Department of Ecology, Lund University. (in Swedish with English summary).

Nilsson, L. \& Persson, H. 1996. The influence of the choice of winter quarters on the survival and breeding performance of Greylag Geese Anser anser. In: M. Birkan, J. Van Vessem, P. Havet, J. Madsen, B. Trolliet \& M. Moser (eds.), Proceedings of the Anatidae 2000 Conference, 
Starsbourg, France, 5-9 September 1994. Gibier Faune Sauvage, Game Wildl. 13: 557-571.

Nordic Greylag Goose Working Group 1988. Noordeuropese Grauwe Ganzen Anser anser in Nederland. Limosa 61: 67-71. (in Dutch with English summary).

Persson, H. 1994. Neck-banding of Greylag Geese Anser anser in Scania, 1984-1993. Anser 33: 101-106. (in Swedish with English summary).

Speek, B.J. \& Speek, G. 1984. Thieme's vogeltrekatlas. Thieme, Zutphen. (in Dutch).

Bergh, L.M.J van den 1991. De Grauwe Gans als broedvogel in Nederland. RIN-rapport 91/1. RIN, Arnhem/Leersum/Texel. (in Dutch).

Voslamber, B. 1993. Grauwe Ganzen bij de Dollard. Aantallen, herkomst en verblijfstijden. De Grauwe Gors 21(34): 92-98. (in Dutch).

Voslamber, B., Zijlstra, M., Beekman, J.H. \& Loonen, M.J.J.E. 1993. Migration of different populations of Greylag geese Anser anser through the Netherlands: differences in area preference and timing in 1988. Limosa 66: 89-96. (in Dutch with English summary).

http://www.knmi.nl/klimaatscenarios/waarnemingen/monitoring_temperature.php (Figure 3)

\section{Sammanfattning}

I början av 1900-talet var grågåsen utrotad i Holland och enbart en genomflyttande art som häckade i Skandinavien och övervintrade i Spanien. Arten etablerade sig sedan åter $\mathrm{i}$ landet och under nittonhundratalets senare hälft ökade antalet med i genomsnitt $20 \%$ per år och beståndet är i dag ungefär 190.000 individer. Flera studier har publicerats om hur utländska bestånd använder Holland som rastplats utanför häckningstiden. Däremot har det häckande beståndets vintervanor inte studerats närmare. I denna uppsats gör vi detta genom att utnyttja observationerna av halsmärkta grågäss under vintern (oktober-mars) under perioden 1 januari 1994 till 1 januari 2010. Totalt använder vi 45.000 observationer av 2500 halsmärkta gäss (Tabell 1).

Märkningarna skedde på ruggningsplatser (Figur 1) från slutet av maj till början av juli. Även om grågäss kan rugga rätt långt från häckningsplatsen har vi antagit att häckningsplatsen för grågässen i denna studie låg nära ruggningsplatsen. Vi fick stöd för detta antagande genom att separat analysera återfyndsmönstret för individer som vi säkert visste var fyra år eller äldre och som hade observerats under häckningsperioden 1 mars till 15 april. Sådana gäss bör nämligen vara lokala häckfåglar. Vi fann att mönstret för dessa gäss var detsamma som för alla gäss, och vi ansåg därför att vi kunde utnyttja hela materialet för i vår analys.

Över 99\% av de märkta fåglarna återsågs minst en gång. I ett särskilt intensivt studerat område
(Ooijpolder, Nijmegen; 'mid' in Table 1) var det genomsnittliga antalet observationer av varje gås väsentligt högre än i andra områden, hela 95 mot ungefär 12 i övriga delar av landet. Men även dessa lägre värden innebar att tillräckligt många observationer kunde analyseras.

Könen skilde sig inte i flyttningsavstånd. Däremot var det stor skillnad mellan de fyra regionerna. Gäss från norra regionen flyttade i genomsnitt näs$\tan 300 \mathrm{~km}$ medan de från de övriga tre regionerna hade medelvärden på under $10 \mathrm{~km}$. Skillnaden beror på att $17 \%$ av gässen från norra regionen flyttade till Spanien, medan motsvarande andel i de övriga tre regionerna var mycket låg. Hela $75 \%$ av de fåglar som återsetts i Spanien, Italien eller Frankrike hade sin hemvist i den norra regionen.

Oberoende av vilka avstånd de olika regionala bestånden flyttade så avtog andelen individer snabbt med ökande avstånd. De flesta fåglar övervintrade mycket nära häckningsplatsen. Detta innebär att varje population har sitt eget hemområde hela året och som är skilt från de andra beståndens (Figur 3). Observationerna utanför Holland kom oftast från platser nära gränsen och bara ett mindre antal från platser på större avsstånd (Figur 4).

Det skedde en kraftig förändring av flyttningsavståndet under studieperioden (Figur 5). Åren 1993 1996 var medelavståndet mellan häckningsplatsen och vinterobservationerna mycket högre än senare. Efter 1996 är det sällan som gäss flyttat längre än $20 \mathrm{~km}$. En felkälla kan vara att flertalet långflyttare före 1997 hade märkts på tre platser: Oostervaardersplasen, De Deelen och Waterland. På Oostervaardersplassen och Waterland har inga gäss märkts efter 1998 och gäss därifrån kan därför teoretiskt fortfarande vara långflyttare. Detta motsägs dock av att gäss från De Deelen, där märkningen återupptogs 2005, har upphört med sin långflyttning också. Endast tre procent av fåglarna märkta i detta område efter 2005 flyttade till Spanien. Vi är anser därför att det är säkerställt att de grågäss som häckar i Holland i princip är stannfåglar numera.

En del andra mönster framträder också. Lokala bestånd, som häckar nära varandra, uppvisar delvis rätt olika spridningsbilder. En hel del gäss flyttar numera norrut och övervintrar i Danmark och i de södra delarna av Norge och Sverige. Utan att vi kan komma fram till några säkra slutsatser om orsakerna till skillnader eller förändringar spekulerar vi om förklaringar som klimatförändring, ändringar i jakttryck, förändring av rapporteringsmönster, och genetiska effekter genom inblandning av förvildade tamgäss. Vi utesluter däremot försämrade födobetingelser under vintern i Holland. 